\title{
Conservatism and the cancer drugs fund
}

\author{
Are some patients-and some people-more deserving than others?
}

\author{
Nicholas S Hopkinson reader in respiratory medicine
}

Imperial College London

Decisions about healthcare inevitably involve the allocation of finite resources. Democracy, if it is meaningful, is public reasoning. The National Institute for Clinical Excellence (NICE), established by Frank Dobson in 1999, though imperfect, represents a worthy attempt to conduct a reasoned assessment of what a health service should provide.

When the Cancer Drugs Fund (CDF) was launched by the Conservative and Liberal Democrat coalition government in 2010, it was presented as a mechanism to provide treatments for patients with cancer in advance of their approval by NICE for use in the NHS. ${ }^{1}$ Yet the fund was criticised as an attempt to undermine the NICE process ${ }^{2}$ and an irrational use of resources. A more recent analysis ${ }^{3}$ noted that "it was created despite a lack of evidence that prioritising drug expenditure would improve outcomes for cancer patients over and above greater investment in the whole cancer management pathway, which includes screening, diagnostics, radiotherapy, surgery, and palliative care." $£ 1.27$ billion was spent, but only 18 out of 47 indications were actually supported by subsequent trial data. This means that many patients were exposed to the toxic side effects of drugs that were in fact ineffective. The authors concluded that the fund "failed to deliver meaningful value."

The CDF represents an opportunity cost, both for cancer patients and for the health system as a whole. Call to mind, for example, the government's crocodile tears on mental health, as services are cut $^{4}$ and the social support structures ${ }^{5}$ that protect the vulnerable are hacked away. Or, more directly relevant to cancer, note extensive cuts to smoking cessation ${ }^{6}$ services.

Which matters more: many people going without what they need, or a few having what they do not deserve?

It is easy to dismiss the CDF as merely an ill thought out election promise, but that risks missing the ideological message at its heart. An essential feature of conservatism is the justification of established social structures. These structures include having some people with a great surplus of goods and power, and tolerating the fact that many lack these in even the most basic form. To a disinterested observer this seems immoral, but we can be tempted to accept these disparities (perhaps from own privileged position) if they can be presented as somehow "deserved." This is expressed in political language by attacks on those receiving benefits as lazy (though unemployment benefit is actually only $1 \%$ of welfare spending ${ }^{7}$ ) and the sick as being harmed by their lifestyle choices (though many of these are not really choices at all). The defining political question can be framed as "which matters more: many people going without what they need, or a few having what they do not deserve?" Politics has focused on the latter, and society is the worse for it.

In establishing the CDF, a political decision was taken: cancer patients were especially "deserving" of treatments. Less deserving were patients with other life limiting conditions, whose access to therapy was inevitably restricted because of the allocation of finite resources. Those with lung cancer were judged to be more deserving than those with lung fibrosis. Not just an election promise, but a very specific category of promise, this type of thinking is wasteful, socially corrosive, and has no place in a just healthcare system.

\section{This article first appeared on BMJ Opinion at} blogs.bmj.com/bmi/2017/05/10/nick-hopkinson-conservatismand-the-cancer-dnugs-fund Competing interests: None declared.

Not commissioned, not peer reviewed.

Cohen D. Most drugs paid for by £1.27bn Cancer Drugs Fund had no "meaningful benefit". BMJ 2017;357:j2097. doi:10.1136/bmj.j2097 pmid:28455308.

2 Maynard A, Bloor K. Regulation of the pharmaceutical industry: promoting health or protecting wealth? J R Soc Med 2015;357:220-2. doi:10.1177/0141076814568299 pmid: 25922427.

3 Aggarwal A, Fojo T, Chamberlain C, Davis C, Sullivan R. Do patient access schemes for high-cost cancer drugs deliver value to society?-lessons from the NHS Cancer Drugs Fund. Ann Oncol 2017. doi:10.1093/annonc/mdx110. pmid:28453615.

4 Hutchinson S. Mental health budgets "still being cut despite pledge." 2016. www.bbc.co. uk/news/health-37657954.

5 Butler P. Vulnerable adults at risk as councils face $£ 1$ bn social care shortfall. 2016. www. theguardian.com/society/2016/jul/13/vulnerable-adult-social-care-risk-england-councilsface-1bn-shortfall.

6 Cancer Research UK. Stop smoking services under threat as budgets are cut. 2016. www.cancerresearchuk.org/about-us/cancer-news/press-release/2016-11-16-stop-smokingservices-under-threat-as-budgets-are-cut?_ga $=2.9644405 .1305776658 .1494430187$ 124268469.1494430187.

7 Office for National Statistics. How is the welfare budget spent? 2016. http://visual.ons. gov.uk/welfare-spending. 
Published by the BMJ Publishing Group Limited. For permission to use (where not already granted under a licence) please go to http://group.bmj.com/group/rights-licensing/

permissions 